University of Arkansas, Fayetteville

ScholarWorks@UARK

4-1-1975

Sodium, Potassium, Calcium and Magnesium Content of

Northwest Arkansas Rain Water in 1974

G. H. Wagner

University of Arkansas, Fayetteville

Follow this and additional works at: https://scholarworks.uark.edu/awrctr

Part of the Fresh Water Studies Commons, and the Water Resource Management Commons

\title{
Citation
}

Wagner, G. H.. 1975. Sodium, Potassium, Calcium and Magnesium Content of Northwest Arkansas Rain Water in 1974. Arkansas Water Resources Center, Fayetteville, AR. PUB029. 22

https://scholarworks.uark.edu/awrctr/307

This Technical Report is brought to you for free and open access by the Arkansas Water Resources Center at ScholarWorks@UARK. It has been accepted for inclusion in Technical Reports by an authorized administrator of ScholarWorks@UARK. For more information, please contact scholar@uark.edu. 


\section{SODIUM, POTASSIUM, CALCIUM, AND MAGNESIUM CONTENT OF NORTHWEST ARKANSAS RAIN WATER IN 1974}

by

G. H. Wagner

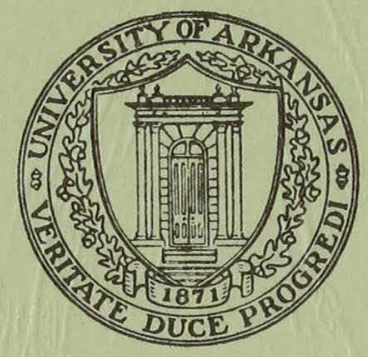

ARKANSAS WATER RESOURCES RESEARCH CENTER

Publication No. 29

April 1975 
SODIUM, POTASSIUM, CALCIUM, AND MAGNESIUM CONTENT OF NORTHWEST ARKANSAS RAIN WATER IN 1974

by

G. H. Wagner

ARKANSAS WATER RESOURCES RESEARCH CENTER

Publication No. 29

Apr11 1975 


\section{Table of Contents}

Int roduction

Page

Experimental

Discussion

Acknowledgement

References

Table I - Rain Water Flux of Elements

Table 11 - 1974 Rainfall, Fayetteville, Arkansas

Table III - Comparison of Concentrations and Concentration Ratios with Those of Previous Workers

Table IV - Contribution of Dry Fallout to Total Flux

Figure 1 - Amount of Rain Per Month

Figure 2 - 1974 Monthly Flux

Figure 3 - Na and Ca Monthly Flux

Figure 4 - K and Mg Monthly Flux

Figure 5 - 1974 Bimonthly Average

Figure 6 - Na and Ca Bimonthly Average Concentration

Figure 7 - $\mathrm{K}$ and Mg Bimonthly Average Concentration

Figure 8 - Average Daily Flux Since Last Rain for 


\section{SODIUM, POTASSIUM, CALCIUM AND MAGNESIUM CONTENT \\ OF NORTHWEST ARKANSAS RAIN WATER IN 1974 \\ G.H. Wagner (Department of Geology)}

\section{Introduction}

The chemical content of rain water is of interest to the soil scientist, silviculturist, ecologist, geochemist, and atmospheric chemist. Chemical flux data for rain water are essential for mass balance studies of streams, basins, impoundments, etc. Such data are sparse for Fayetteville, for Arkansas and for the midcontinent area. For this reason we began last year to analyze and to publish the concentration and flux data for the four subject elements in Fayetteville rain water. The first publication (Wagner and Holloway, 1974) gave data on the individual rains, monthly averages, and yearly totals for 1973. In the present report similar data are presented for the 53 rains which fell on Fayetteville in 1974 .

Junge and Werby obtained chemical data on rains for a network of sampling stations across the nation in 1955-56. The data have been published only as yearly averages in map form (Junge, 1958, 1963; Junge and Werby, 1958). Lodge, et al (1968) obtained average values for 1960-66 using a national network of sampling stations, the nearest station to us being Springfield, Missouri, 175 kilometers northeast of Fayetteville. In Table I, flux data on 1974 rains for Fayetteville are compared to that of these previous workers.

The 1974 fluxes agree very closely for sodium and potassium with that of Junge and Werby but are $24 \%$ less in 1974 in calcium. Compared to 
1973 data, the 1974 data are $8 \%$ less in sodium, $38 \%$ less in potassium, $12 \%$ greater in calcium, and $13 \%$ less in magnesium. Both Junge and Werby and Lodge et al report to using collectors which opened only during a rain and thus measured wet fallout only. We have used a collector which was opened at all times and thus should obtain the sum of dry and wet fallout. This aspect of our data will be elaborated on later in this report. Another difference is the greater amount of rainfall in 1974 (46\% more) and 1973 (94\% more) over that in 1955-56.

\section{Experimental}

The equipment used to collect the rain samples was designed for radiochemistry work and has been described elsewhere (Daniel, 1974). A $3 \times 3$ meter galvanized steel sheet was the collecting area; a central drain hole led to a 120-liter polyethylene bottle. The collector was open between rains. Concentrated nitric acid at $2.4 \mathrm{ml}$ per liter of rain water was added on the day of collection and the acidified samples were stored in polyethylene bottles. Samples of rains from January through June of 1974 were analyzed in July, 1974. Samples from July through December rains were analyzed in January, 1975. The samples were not filtered because no difference was found on analyzing a trial lot of filtered and unfiltered samples.

All four elements were determined with a Perkin Elmer Model 303 spectrophotometer using the prescribed methods of the Perkin Elmer handbook (1971). Absorption measurements on duplicate samples generally gave better

than $\pm 10 \%$ agreement with sodium and potassium giving the greatest variability. An air-acetylene flame was used for each element. However, air-hydrogen 
was used to analyze 31 samples for potassium and compared with the results obtained with the air-acetylene flame. The air-hydrogen determinations averaged $5.2 \%$ lower for the 31 samples. This is considered within experimental error and indicative of no significant ionization interference in the air-acetylene flame with these rain samples.

\section{Discussion}

In Table 11 data for the 1974 rains are summarized in terms of monthly and yearly averages of concentration and flux. Yearly values for 1973 are shown for comparison. Yearly average concentration values for 1974 rains compared to 1973 rains are $22 \%$ greater for sodium, 17\% less for potassium, 48\% greater for calcium and 15\% greater for magnesium. Concentration averages are weighted averages since they were determined by summing the monthly fluxes and dividing by the yearly rainfall in centimeters.

Total yearly rainfall was $25 \%$ less in 1974 than in 1973. As shown in Figure 1 where monthly rainfall in $\mathrm{mm}$ is compared graphically for the two years, the monthly trends are similar with spring and fall peaks and summer lows shown by both 1974 and 1973.

Figure 2 portrays the monthly variation in the flux of each element. All four elements have low fluxes in the winter months but peak values vary from September-October for calcium and potassium, May-June for sodium, and July-August for magnesium. Figures 3 and 4 compare the 1974 monthly fluxes for the four elements with their 1973 values. Except for sodium, one is struck by the dissimilarity of the monthly trends for the two years. For example calcium has its peak flux in March-April in 1973 and in SeptemberOctober in 1974. Generally the maximum flux of each element came in the 
spring in 1973 and in the fall in 1974 (except $\mathrm{Na}$ ). This is probably due to the much greater amount of rain in the spring of 1973 compared to the spring of 1974 and to the maximum rainfall in 1974 occurring in the fall.

In treating monthly fluxes it will be noted that averages over a two month period have been used. Since we used an open collector, a condition of no rain in the latter part of a month adds appreciable dry fallout to the first rain in the next month. Thus a monthly average derived from averaging the values for two successive months will more accurately measure the dry plus wet fallout for one month.

Bimonthly average concentrations of sodium, potassium, calcium and magnesium are plotted in Figure 5 for the various months of the year. The general trend of the concentration values is to rise in those months with low rainfall and to fall in those months with high rainfall. It is as if there were a more or less constant amount of fallout to be dissolved in a varying amount of rainfall. Figures 6 and 7 compare the monthly variation of concentration of the individual elements for 1974 and 1973. Sodium and calcium variations are very similar for the two years whereas potassium and magnesium are very different, although similar in each year.

Table III compares the yearly average concentration and concentration ratios of the four elements with those of other workers. Compared to Junge's measurements, the 1974 concentration ratios are very similar but the yearly average concentrations are lower: $42 \%$ for sodium, $41 \%$ for potassium and $94 \%$ for calcium. The elemental ratios for Fayetteville are similar to crustal rocks not seawater as shown by comparison with the last two lines in Table 111 . This indicates that soil dust not sea water aerosols is the source for the chemicals in Fayetteville's rain water. As pointed out by 
Junge and Werby (1958), the contribution of sea salts to rain water diminishes to a very small value 500 miles from the seacoast, which is about the distance for Fayetteville.

It was of interest to estimate the dry fallout contribution to the 1974 results. In a previous report (Wagner and Holloway, 1974) dry fallout was estimated by plotting monthly flux versus monthly rainfall in mm and extrapolating to zero rainfall, the intercept on the flux axis being the dry fallout monthly flux. This method can give an inequitable distribution of dry fallout between months when a month with no rain for several days in the latter part of the month is followed by a month with rain in the first few days. Use of bimonthly averages avoids some of this problem. However we have chosen for this report another method for estimating dry fallout.

Each rain, when using an open collector, consists of a wet fallout portion and a dry fallout portion. The dry fallout portion is equal to the sum of the daily dry fallout fluxes since the last rain. For light rains the dry fallout contribution is, of course, magnified and the lighter the rain, in $\mathrm{mm}$, and the greater the number of days since the last rain, the greater the dry fallout contribution. In Figure 8 the average daily flux since the last rain has been plotted against the $\mathrm{mm}$ of rainfall for 1974 rains of approximately 20 mm and less. In making the average daily flux calculations the wet fallout contribution is assumed to be zero. There is undoubtedly great variability in the dry fallout flux from day to day as has been found for wet fallout which accounts for the scatter of the points. Extrapolating the envelopes of the data in Figure 8 to zero rainfall eliminates the wet fallout portion and gives the average dry fallout flux as the mid point (indicated by arrow) of the band on the flux axis.

Table IV gives the dry fallout contribution for each of the four 
elements as determined by the above method. The wet fallout as a percentage of the total is calculated by difference and is compared to a previous estimate (Wagner and Holloway, 1974) for 1973 rains. For each year, the wet fallout for each element is very roughly about one-half of the total fallout. In precise terms the wet fallout, as a per cent of total, for 1974 compares to 1973 as follows: 8\% more for sodium, potassium, and magnesium and 15\% less for calcium.

\section{Acknowledgement}

Mr. R.W. Holloway kindly made available the rain samples used in this work, their associated records and data, and was helpful in the interpretation.

This study was supported in part by funds from the Office of Water Resources Research, United States Department of the Interior, as authorized under the Water Resources Act of 1964, Public Law 88-379, and administered through the Water Resources Research Institute for Arkansas. 


\section{References}

Daniel, Patsy Y., 1974. Radioactive strontium isotopes in the atmosphere, Ph.D. thesis, University of Arkansas (available on interlibrary loan).

Junge, C.E., 1963. Air chemistry and radioactivity. International Geophysics Series, Vol. 4. Academic Press, New York.

Junge, C.E., 1958. Atmospheric chemistry. In Advances in Geophysics (H.E. Landsberg and L. Van Micghan, eds.) 4, 1-101. Academic Press, New York.

Junge, C.E. and Werby, R.T., 1958. The concentration of chloride, sodium, potassium, calcium and sulfate in rain water over the United States. J. Meterol. 15, 417-425.

Lodge, J.P., Jr., Pate, J.B., Basbergill, W., Swanson, G.S., Hill, K.C., Lorange, E., and Lazrus, A.L., 1968. Chemistry of United States precipitation sampling network. Final report on the national precipitation sampling network. Laboratory of Atmospheric Sciences, National Center ror Atmospheric Research, Boulder, Colorado.

Mason, Brian, 1966. Principles of geochemistry, 3rd Edition. John Wiley and Sons, New York.

Wagner, G.H. and Holloway, R.W., Sodium, potassium, calcium and magnesium content of Northwest Arkansas rain water in 1973 and trace metal analyses of 1974 rains, Arkansas Water Resources Research Center, Publication No. 25, 21 p. 
Table I. Rain Water Flux of Elements

Place

Fayet teville, Ark.

Fayetteville, Ark.

Fayet teville, Ark.

Springfield, Mo.
Amount of

Yr. Rain (mm)

1974

1973 Holloway (1974)

$1955-56$

$1960-66$
1872

Wagner and

965

Junge and Werby (1958):

1408 This report

Lodge et $\frac{\text { al }}{(1968)}$

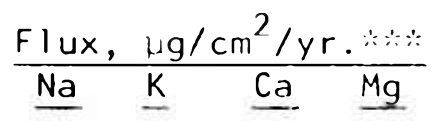

$29.7 \quad 19.9 \quad 160 \quad 11.7$

$\begin{array}{llll}32.3 & 32.3 & 143 & 13.5\end{array}$

$\begin{array}{llll}28.8 & 19.2 \quad 212 \quad-\end{array}$

$53 \quad 36 \quad 405-$

$*$ Concentrations interpolated from their isopleth maps. Amounts of rainfall taken from records of the Fayetteville station.

$\therefore$ Concentrations given in reference. Amount of rainfall taken from records of Springfield station.

$\therefore$ This table is repeated below in units of $\mathrm{lb} / \mathrm{sq} . \mathrm{mi} / \mathrm{day}$

Flux, Ib/sq. mi/day

$\underline{\mathrm{Na}} \quad \underline{\mathrm{K}} \quad \underline{\mathrm{Ca}} \quad \underline{\mathrm{Mg}}$

$\begin{array}{llll}4.64 & 3.11 & 25.0 & 1.83\end{array}$

$\begin{array}{llll}5.04 & 5.04 & 22.4 & 2.12\end{array}$

$4.50 \quad 3.00 \quad 33.2=$

$\begin{array}{llll}8.28 & 5.62 & 63.3 & -\end{array}$ 
Table 11

1974 Rainfall, Fayetteville, Arkansas

$\underline{N a}$

$\underline{K} \quad \underline{\mathrm{Ca}} \quad \underline{\mathrm{Mg}} \quad \underline{\mathrm{mm}}$

Concentration (ppm), average in month

January

February

March

April

May

June

July

August

September

October

November

December

January

February

March

April

May

June

July

August

September

October

November

December

1973 Rains

1973 Rains
0.306

0.206

0.194

0.183

0.200

0.254

0.754

0.141

0.108

0.333

0.193

0.114

0.306

0.182

0.166

0.127

0.103

0.099

0.485

0.093

0.098

0.270

0.116

0.077
3.670

1.432

0.945

0.836

0.760

0.666

5.374

0.621

0.614

2.552

0.741

1.077

Flux $\left(\mu \mathrm{g} / \mathrm{cm}^{2}\right)$, for month

0.794

1.387

1.981

2.979

3.505

4.026

3.965

1.867

2.264

3.263

2.795

0.900

Flux $\left(\mu \mathrm{g} / \mathrm{cm}^{2}\right)$, Year's Total

29.7

32.3

19.9

32.3

160

143
0.140

0.088

0.074

0.074

0.061

0.072

0.417

0.060

0.047

0.151

0.053

0.043

25.91

67.31

102.11

162.82

175.26

158.24

52.58

131.58

210.05

98.05

144.78

78.99

$\begin{array}{lrl}0.792 & 9.500 & 0.363 \\ 1.225 & 9.639 & 0.592 \\ 1.695 & 9.650 & 0.756 \\ 2.068 & 13.612 & 1.205 \\ 1.805 & 13.320 & 1.069 \\ 1.567 & 10.545 & 1.138 \\ 2.549 & 28.257 & 2.192 \\ 1.221 & 8.179 & 0.791 \\ 2.064 & 12.892 & 0.987 \\ 2.648 & 25.023 & 1.482 \\ 1.686 & 10.726 & 0.769 \\ 0.605 & 8.507 & 0.342\end{array}$

Concentration (ppm), Yearly Average

$\begin{array}{llll}0.211 & 0.142 & 1.136 & 0.083 \\ 0.173 & 0.172 & 0.767 & 0.072\end{array}$


Table 111

Comparison of Concentrations and Concentration

Ratios with Those of Previous Workers

\section{Concentration (ppm)}

$\underline{\mathrm{Na}} \quad \underline{\mathrm{K}} \quad \underline{\mathrm{Ca}} \quad \underline{\mathrm{Mg}}$

Lodge, et al, 1960-66

(average for period)

Springfield, Mo.

Junge, 1955-56

(yr average)

Fayetteville, Ark.*

0.30

0.20

2.2

0.67

7.3

Wagner and Holloway,

1973

(yr. average)

Fayetteville, Ark.

0.173

$0.172 \quad 0.767$

0.072

0.994

4.43

0.416

Present Work, 1974

(yr. average)

Fayetteville, Ark.

0.1421 .136

0.083

0.673

5.38

0.393

Seawater

Crustal rocks $* *$

* interpolated from maps of Junge and Werby (1958)

$* *$ Mason (1966)

\section{Concentration Ratios}

$\underline{\mathrm{K} / \mathrm{Na}} \quad \underline{\mathrm{Ca} / \mathrm{Na}} \quad \underline{\mathrm{Mg} / \mathrm{Na}}$

$0.68 \quad 7.6$ 
Table IV

\section{Contribution of Dry Fallout To Total Flux}

\begin{tabular}{|c|c|c|c|c|}
\hline & & $\mu \mathrm{g} / \mathrm{cm}^{2}$ & & \\
\hline & $\underline{\mathrm{Na}}$ & $\underline{K}$ & $\underline{\mathrm{Ca}}$ & $\underline{\mathrm{Mg}}$ \\
\hline Average daily dry fallout flux:: & 0.032 & 0.021 & 0.24 & 0.012 \\
\hline Yearly flux (daily dry fallout flux $\times 365$ ) & 11.7 & 7.7 & 88 & 4.4 \\
\hline Yearly fiux, measured (dry + wet fallout) & 29.7 & 19.9 & 160 & 11.7 \\
\hline Yearly flux, wet fallout (by difference) & 18.0 & 12.2 & 72 & 7.3 \\
\hline Wet Fallout (\% of Total, 1974) & 61 & 61 & 45 & 62 \\
\hline Estimate of $\%$ Wet Fallout in 1973 rains:*: & 53 & 53 & 60 & 54 \\
\hline$*$ From Figure 8 extrapolations & & & & \\
\hline$\therefore *$ Wagner and Holloway (1974) & & & & \\
\hline
\end{tabular}




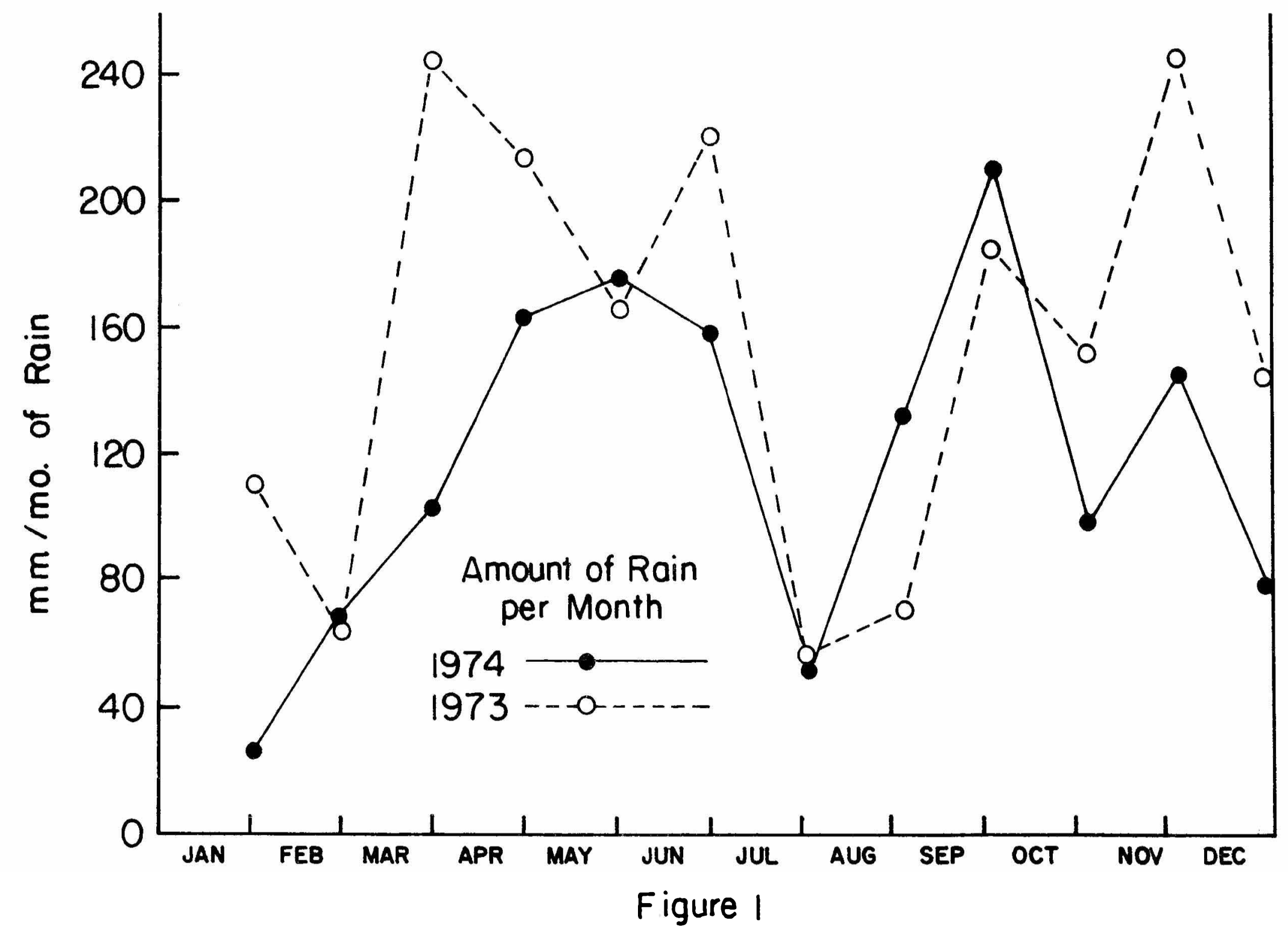




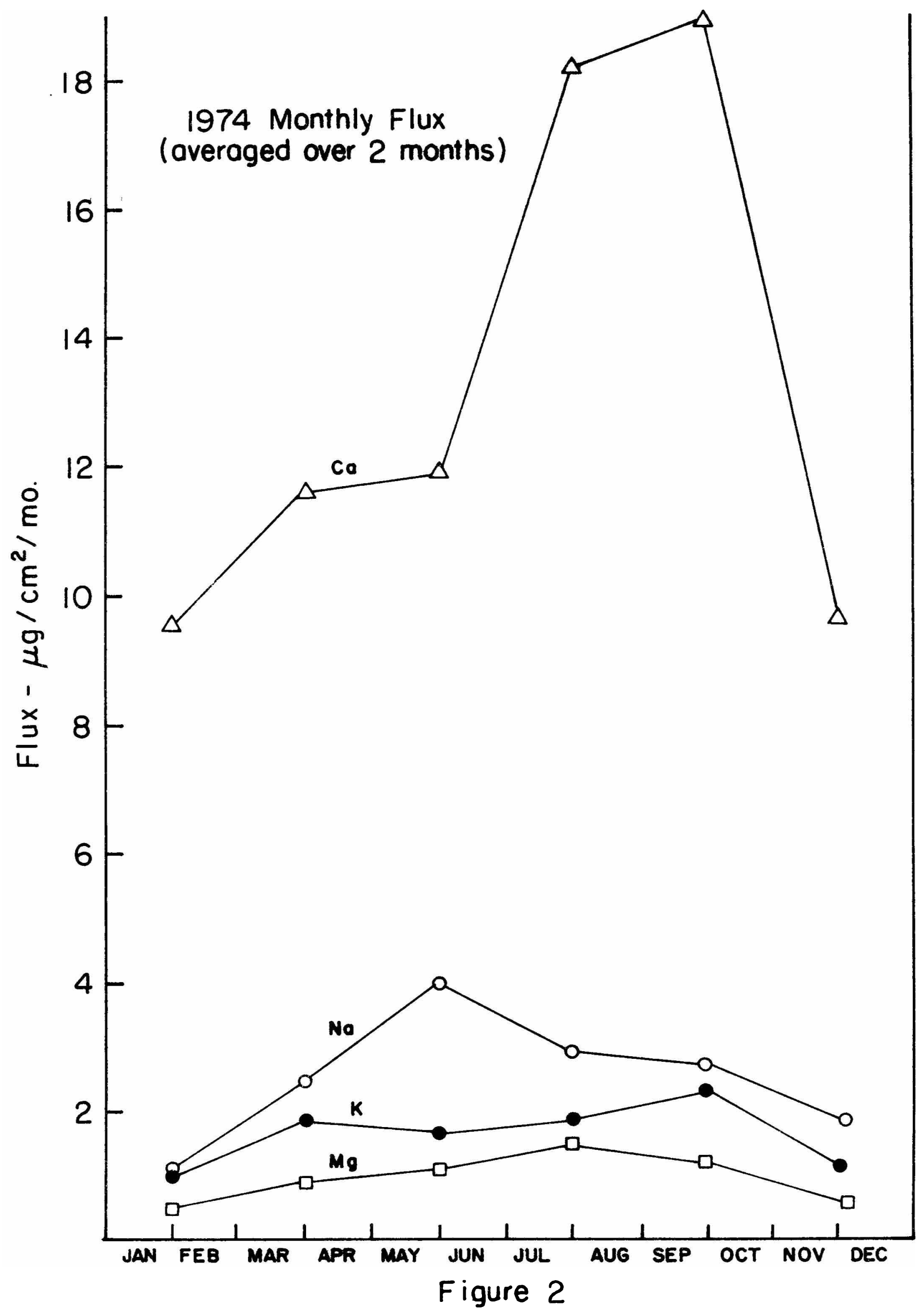




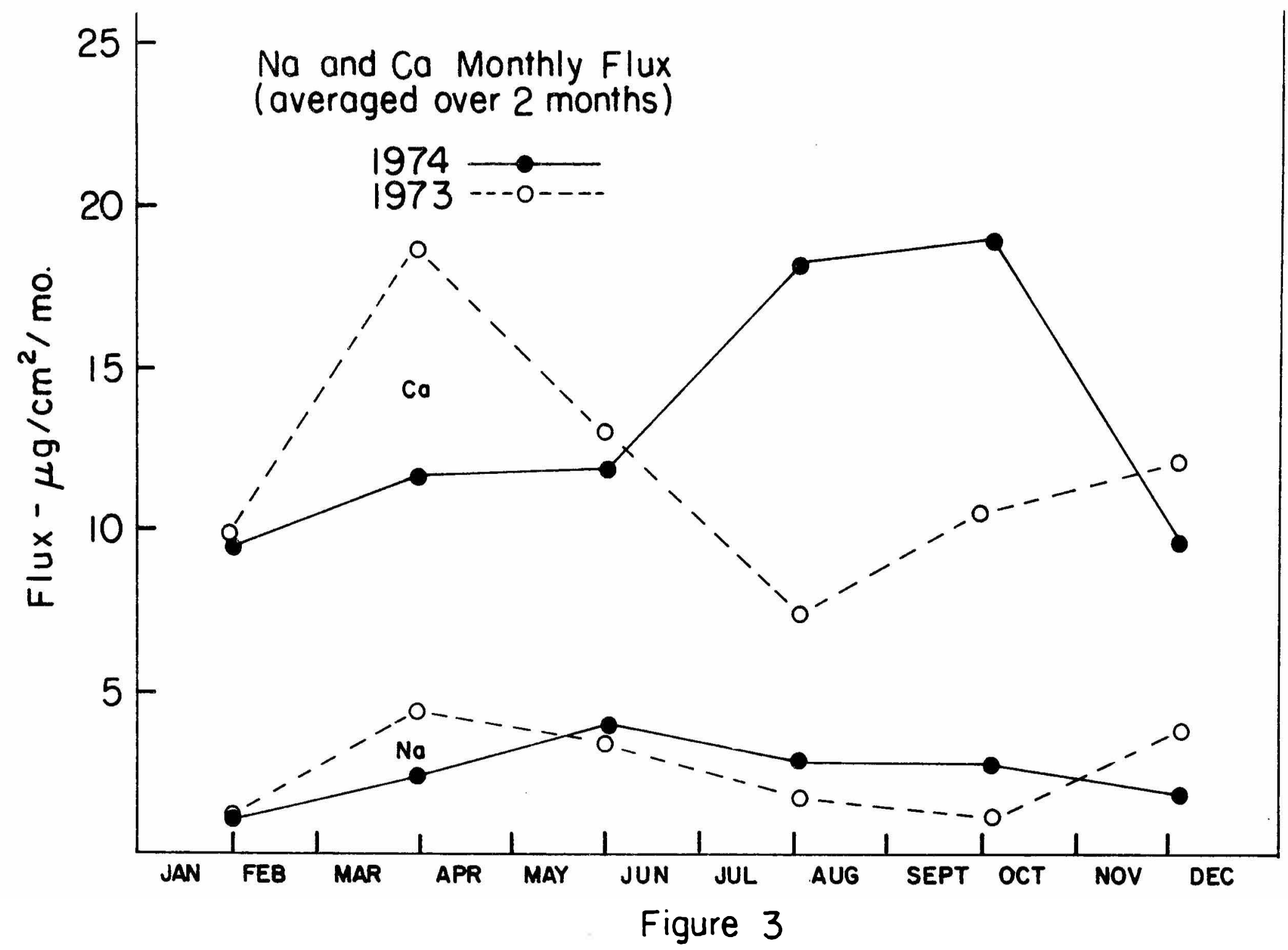




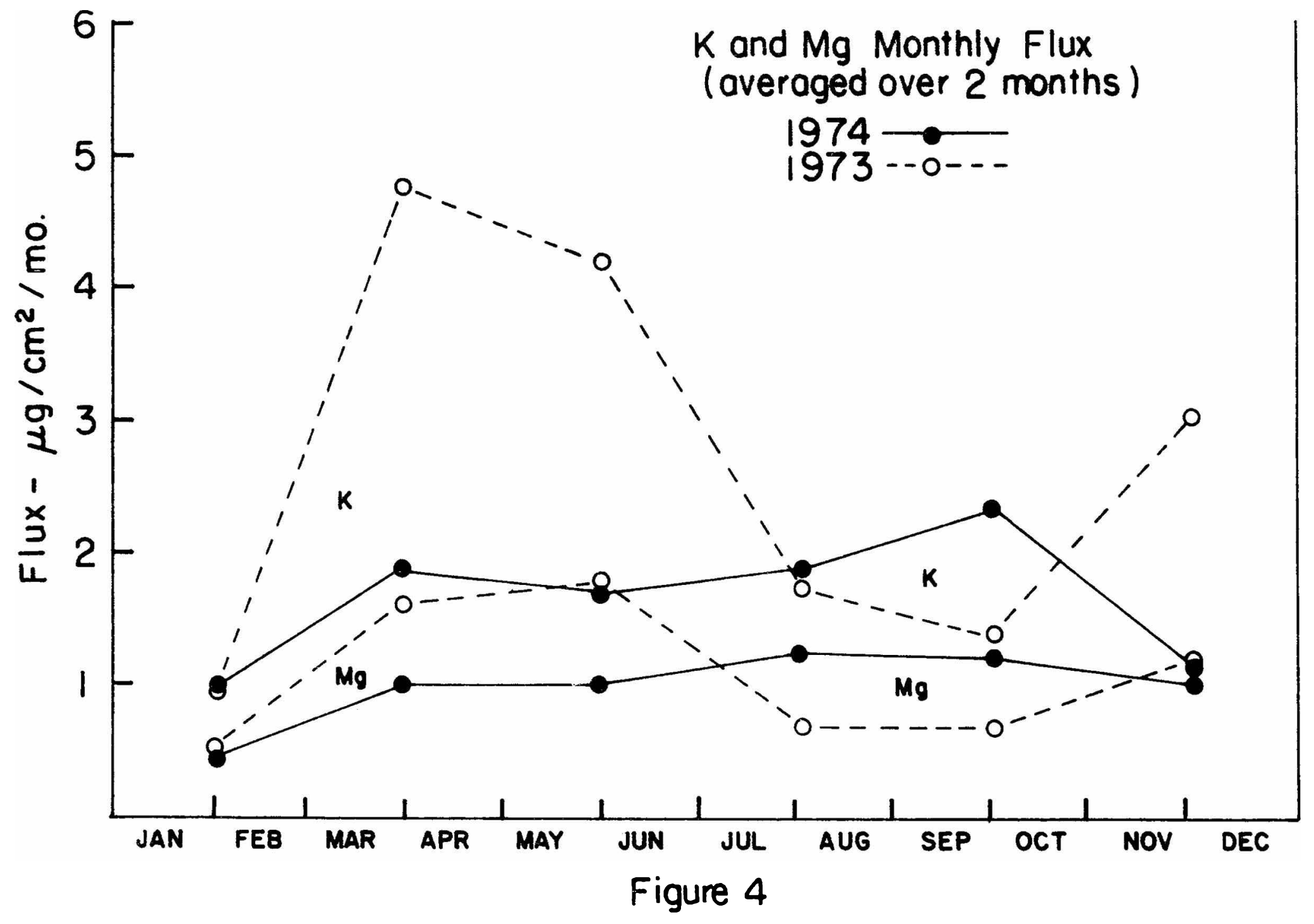


1974 Bimonthly Average Concentration

in Rainfall

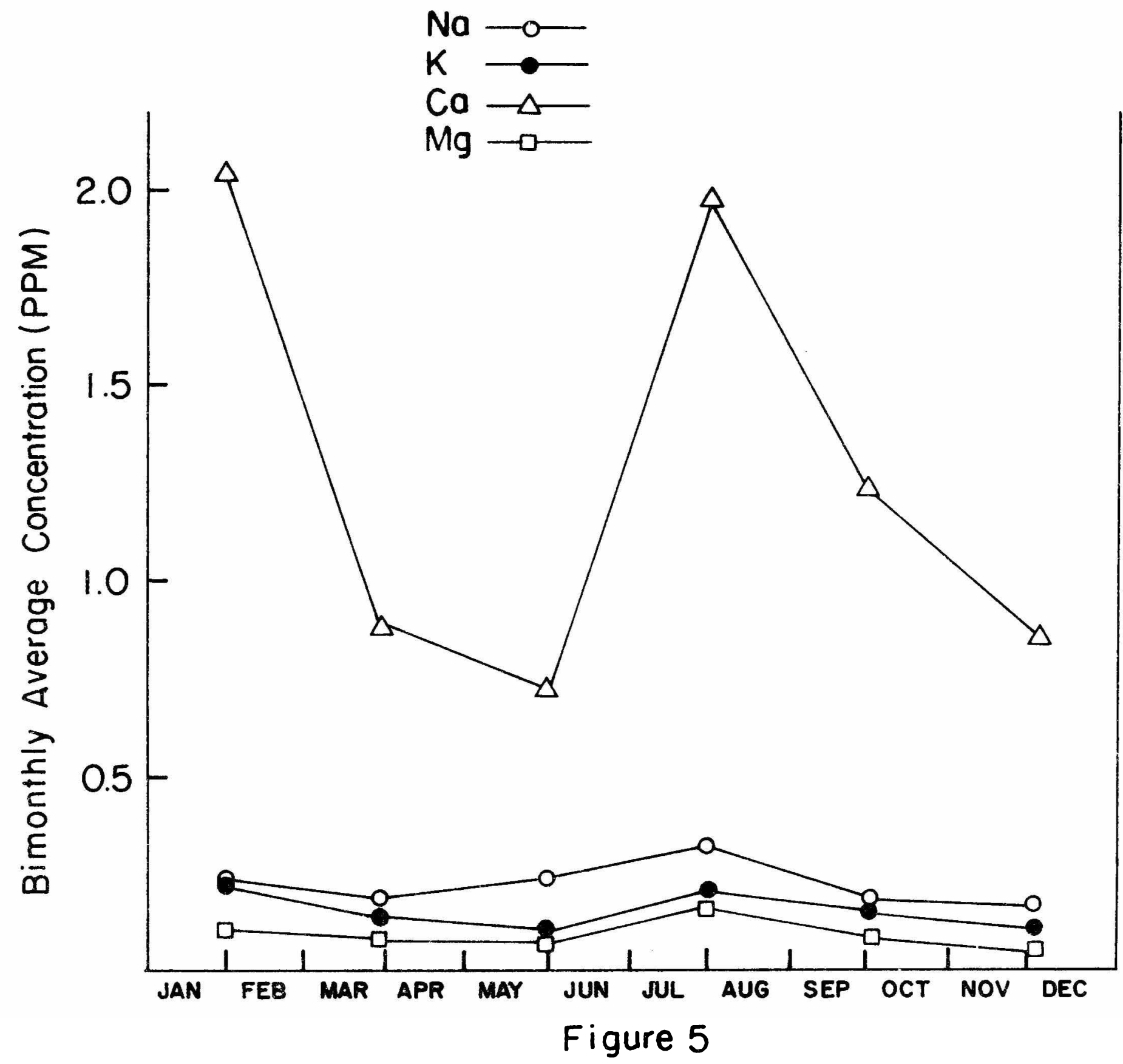




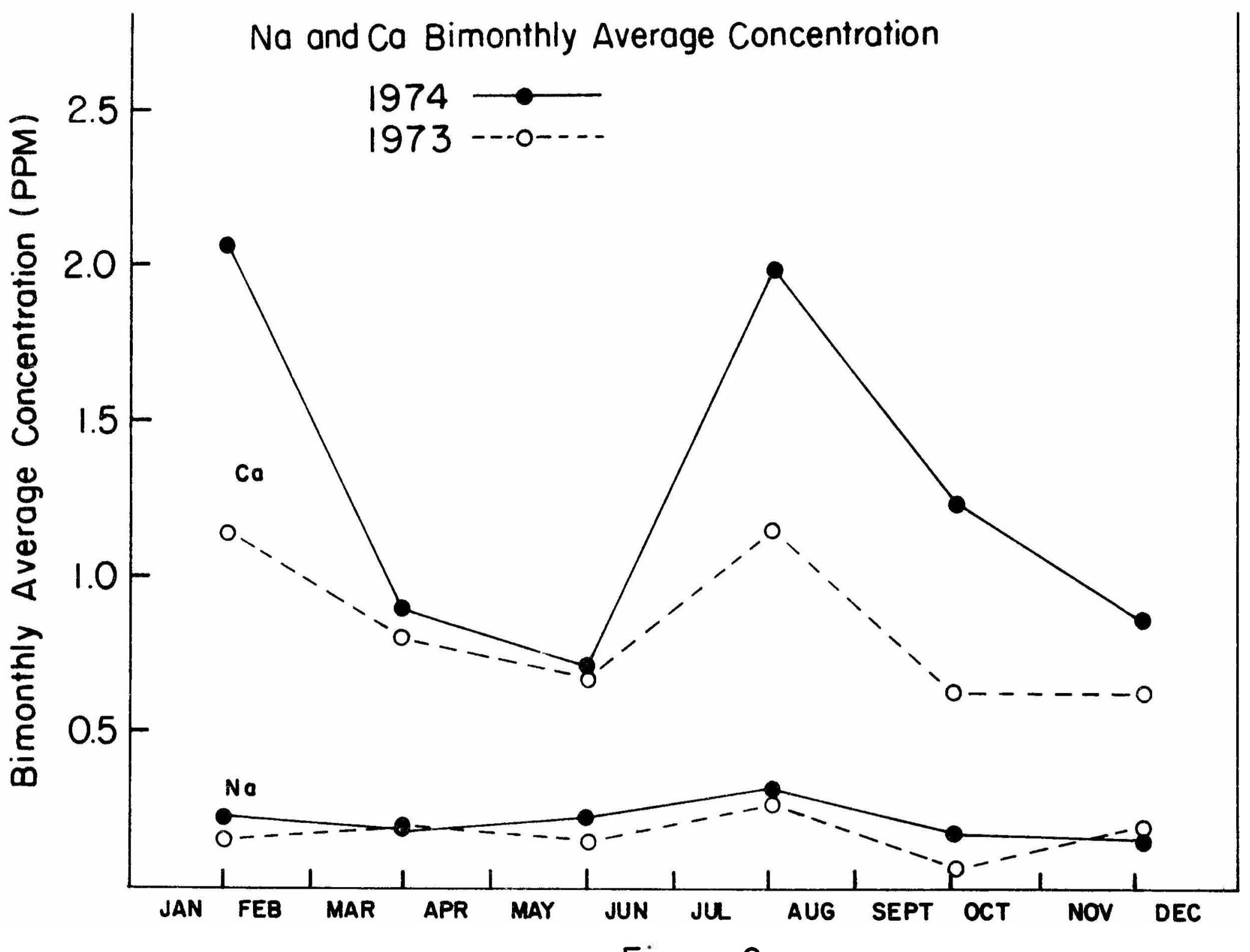

Figure 6 


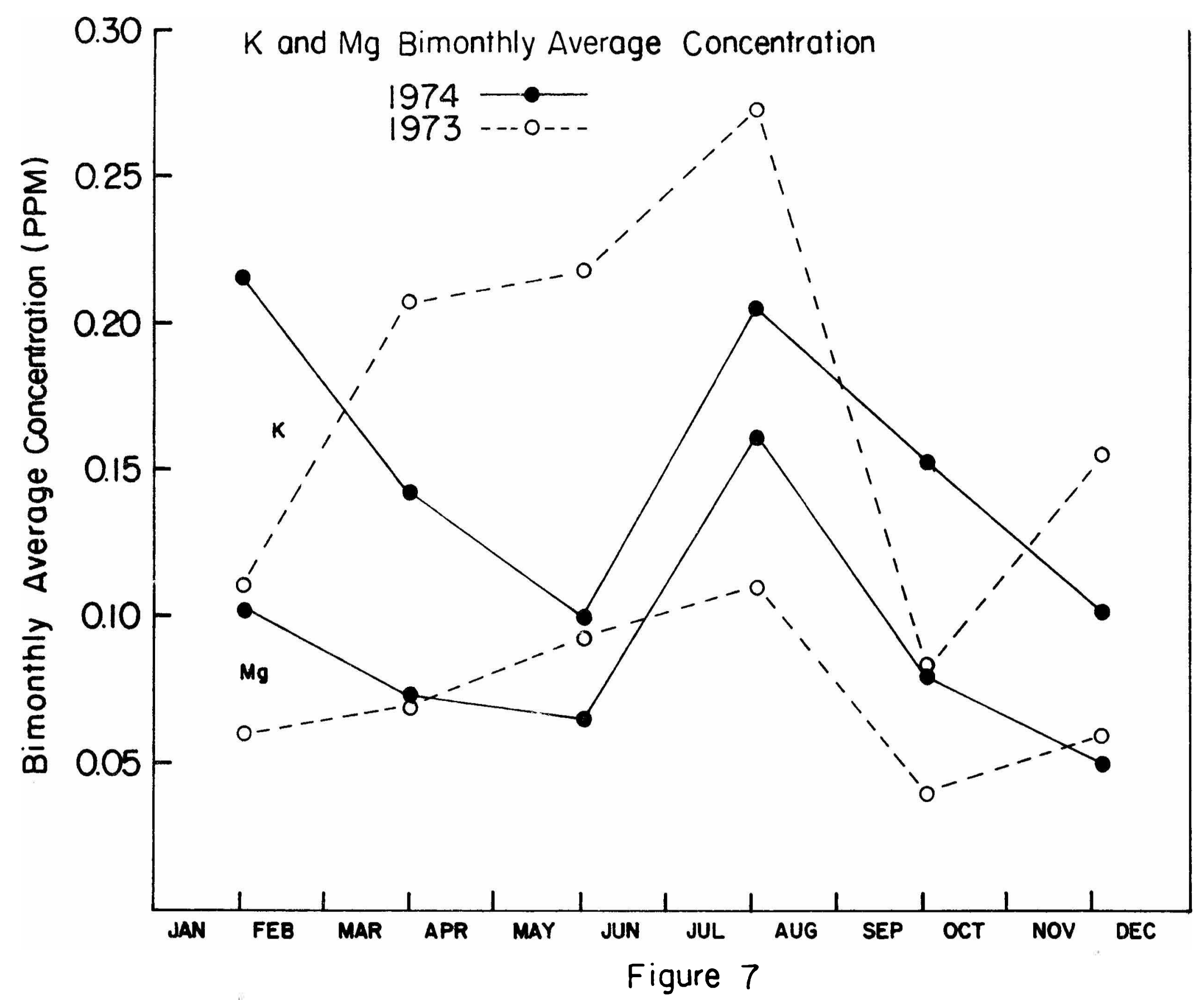




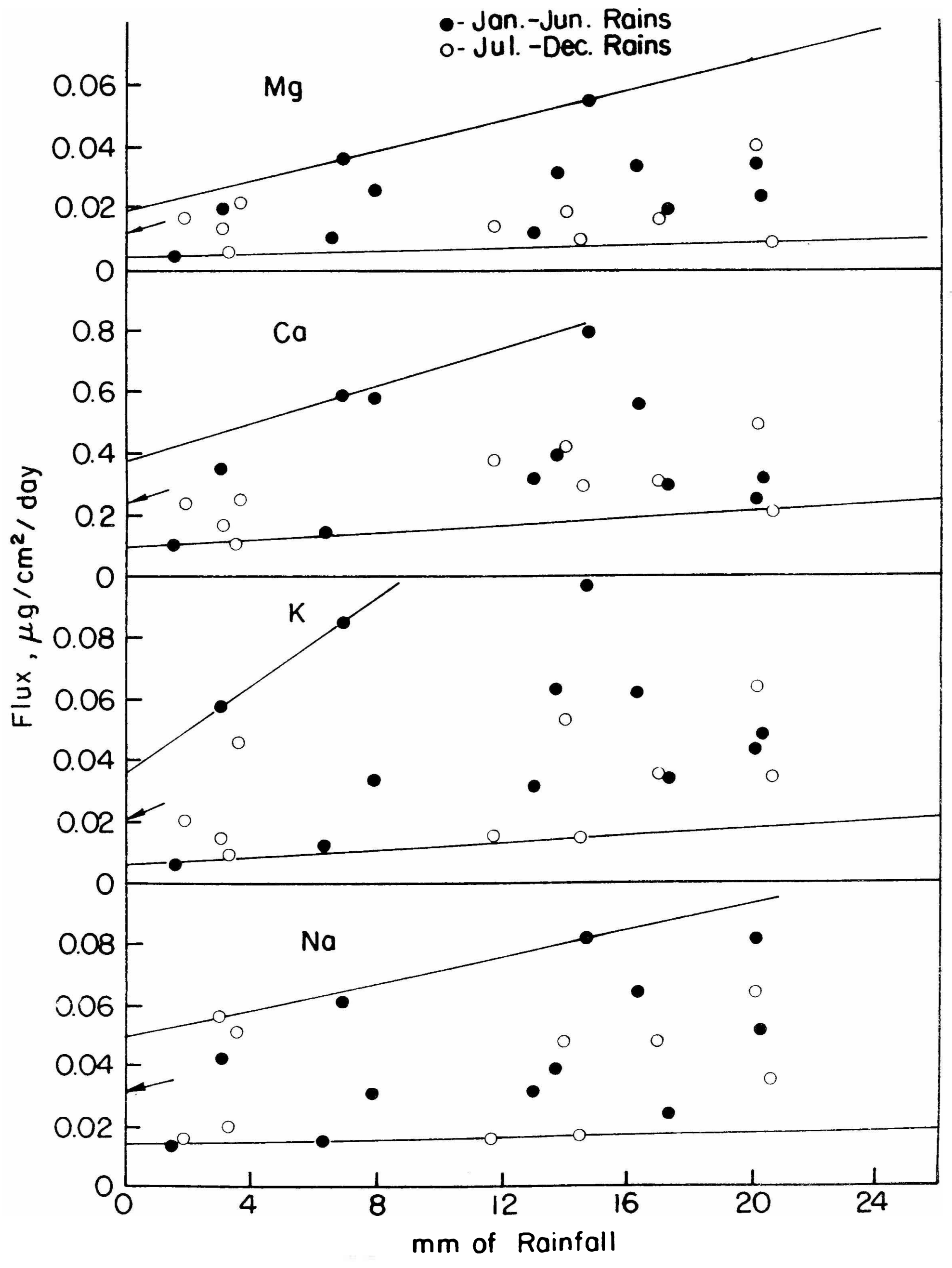

